\title{
How Does a World View Change? \\ (As Illustrated by the Formation of Yerevan as a Socio-Psychological Community)
}

\author{
Svetlana V. Lourié* \\ Sociological Institute of the Russian Academy of Sciences \\ 31 Kostromskoi, Saint-Petersburg, 194214, Russia
}

Received 14.08.2018, received in revised form 26.09.2018, accepted 10.10.2018

The article is devoted to the issue of self-organization of a society. Such self-organization can occur spontaneously and is a manifestation of ethno-cultural processes that occurred not by a decision of public and political figures, although a direction of social transformations depends on their value dominants. Spontaneous social transformations are based on a functional intra-cultural conflict. A mechanism of the society transformation is studied by the example of formation of Yerevan as a socio-cultural community in the middle of the $20^{\text {th }}$ century.

Keywords: ethnoculture, ethno-cultural processes, self-organization of society, cultural theme, functional conflict.

Research area: culturology.

Citation: Lurie, S.V. (2018). How does a world view change? (As illustrated by the formation of Yerevan as a socio-psychological community). J. Sib. Fed. Univ. Humanit. soc. sci., 11(12), 1991-2020. DOI: 10.17516/1997-1370-0332.

\section{What is the spontaneous self-structuring of society?}

Tradition is a fundamentally dynamic and self-developing phenomenon. The development of tradition can be divided into creative and conservative periods. The conservative period, as a rule, follows the creative one, and it corresponds to a smooth and peaceful existence of an ethnos. The creative period is often associated with a charismatic personality that sets the origin of tradition and supports its development. Though it is not always this way. As a rule, on the contrary, it is difficult to identify one certain personality that would lay the foundations of tradition. Often, the formation of tradition seems to be a mass creative work, and it is a theme, an idea, which may not

(C) Siberian Federal University. All rights reserved

* Corresponding author E-mail address: svlourie@gmail.com

This work is licensed under a Creative Commons Attribution-NonCommercial 4.0 International License (CC BY-NC 4.0). 
have an exact specific authorship, that turns to be charismatic. Stiffening of charisma that S. Eisenstadt wrote about ("Tradition is a stiff charisma" (Eisenstadt, 1973: 124)) is not due to the fact that charismatic personalities are becoming extinct from society. No, it is just that now they are changing their dominants, they are "working" to preserve tradition. Of course, we are talking about dominants of certain personalities, but since their dominants are associated with the norms of the emerging, new traditional society, these people cannot always be singled out from it by research methods. We define their type of consciousness as self-responsible (personal), in contrast to the traditional consciousness inherent in the majority of members of both archaic and modern societies. Let us recall that Eisenstadt called modernity a variation of tradition (Eisenstadt, 1973: $335)$.

\section{In the process of transformation or preservation of tradition, the leading role} is played by the so-called carriers of self-responsible consciousness. It is expressed in a special mode of attitude to reality inherent in a person who can take responsibility for each step. Every person can have self-responsible consciousness, since he is given free will, but in reality not so many people show it. It is least of all determined by society. But this does not mean that self-responsible consciousness is extra social. Its dominants are largely associated with the social environment, with the needs of society, and some of these dominants can directly relate to the social and even political sphere. But there is always a free choice, a personal choice that cannot be fully predetermined by anything external. Self-responsible consciousness is not necessarily associated with the capacity for reflection and abstract thinking. It can also be weakly-reflectable. A person with self-responsible consciousness can live in full accordance with traditional ethnic culture, but in a critical situation, he will have a personal reaction. He does not have to become an outcast or an outsider in the traditional society. Carriers of self-responsible (more often, weakly-reflectable) consciousness guarantee its "good quality". They keep the stability of society. A carrier of self-responsible consciousness can consciously get out of its traditional society, and at the same time can consciously stay in it in order to change or preserve it.

The process of the formation of a new tradition and its crystallization even by the carriers of self-responsible consciousness is not always reflected and, as a rule, is not intentional. But it is these people who support traditional life in society making it capable of both spontaneous, rapid, but positive changes and slow, gradual development.

Ethnic culture is not an unchanging mechanism. Since cultural constants have been passed on from generation to generation throughout the centuries, without fading 
away and almost without distortion, it is obvious that the very distribution of culture among its carriers must be such as to ensure its reproduction. And the "energy" sources of ethnic culture should not be outside, but within it. Inside the ethnos, within a certain intracultural group, there must be people whose attitude to the tradition is essentially different from the other members of the traditional society. It is those who have chosen the main dominants of the cultural tradition consciously by themselves.

The ethnos's choice of the value orientation is by no means impersonal. It is made by certain people - carriers of self-responsible consciousness. Other members of the traditional society often simply follow them and take their value orientation. In the traditional society, these people have their own special place and their own special function that is ultimately a function of advisers no matter how it may be expressed externally.

Without support of the carriers of self-responsible consciousness associated with the traditional one, slow and hardly noticeable changes begin to occur in the society, the consequences of which can turn out to be very significant and lead to the destruction of traditional consciousness.

Traditional consciousness of an ethnos is by no means an absolutely stable formation. Stability can be shaken, in particular, by the inadequacy of its adaptive properties when conditions for the existence of an ethnos change. From time to time, dysfunction of traditional consciousness may occur, and the ethnos experiences a state of distemper. Therefore, within the traditional society, there is a mechanism for regulating the accumulated tension, which is included in periods of distemper. Then the system can go out of its "framework" to release the excess energy, but then return back to its own framework, go on its track again. But the return does not happen automatically. The state of distemper can be defined as a crisis of self-identification: people stop correctly defining the "we-image", adequately mark danger and inscribe it in the structure of being that is present in their traditional consciousness. As a result, there occurs psychological fatigue of the traditional society and apathy.

It is here where the carriers of self-responsible consciousness can recall the initial connections, those that were lost or "darkened" during the period of distemper. Such people give the system the opportunity to return to the original state or to find a new stable one. They help to restore a normal, adequate transfer process.

The escape of carriers of self-responsible consciousness from the traditional society leads to a state of distemper in it, "obscuring" of the above images and patterns of behaviour. And on the contrary, in accordance with the traditional consciousness their life stabilizes the activity, behavioural patterns inherent in the traditional society. 
Each society has its main cultural theme, which initially, in the period of formation of the traditional cultural community, appears in its synthetic integrity, it is one for the traditional society. It is explicated only gradually, and it is gradually divided into internal alternatives, that is, its different interpretations. The division into internal alternatives leads to an intra-cultural conflict that, at first, may seem even dysfunctional. In time, its functional significance will become clear. The basis of transformations of traditional consciousness and the traditional system of institutes is a functional intra-cultural conflict, that is, such a conflict between representatives (and primarily carriers of self-responsible consciousness) of various internal cultural alternatives of the ethnos, which ultimately serves the prosperity of the ethnos as a whole.

A conflict is the driving force behind the development of the traditional society. It serves as a drive that animates intra-cultural groups, activates the reproduction of relevant cultural content. But at the first stage of the formation of a traditional society, while the system is not yet adapted to a functional intra-cultural conflict, it can significantly disrupt communication and sociality accepted in the society, there is a threat of culture dysfunction and distemper. Subsequently, the sociocultural structure of society becomes more complex, the system becomes not just resistant to the conflict, but the sociocultural structure of society itself becomes a mechanism, on the basis of which a functional intra-cultural conflict is reproduced.

A functional intra-cultural conflict that is developing around the main cultural theme of the ethnos. The conflict is initially played out spontaneously, later acquiring scenario, plot features, and then becomes a functional-activity model.

The intra-cultural conflict can be based on the internalization of strife, when the causes of the conflict are introduced into themselves by an ethnos and are resolved within themselves, or on the exteriorization of strife, when the conflicting elements are brought out to reality that is external in regard to the ethnos.

In order for the functional intra-cultural conflict could be realized, the division of society into intracultural groups should be carried out. These groups can have very different features. In general, a social picture of society depends on the mechanism for responding to conflict, that is, society (ethnos) internalizes or exteriorizes the conflict. When the society internalizes the conflict, its structure is outlined more vividly and value-based, the society is more clearly divided into internal alternatives that oppose each other. When the conflict is exteriorized, the intra-cultural groups are less opposed to each other in terms of the value principle; the intra-group and 
inter-group communication is becoming more important. The society aimed at the exteriorization of the conflict is the most dense, the differences and the features of value orientations do not become an excuse for opposition in the society as a whole or any part of it, or, perhaps, in its own group. In such a society, an individual has a multitude of communication links that reduce his potential proneness to conflict. All the potential of the social system is directed towards this goal and the inner proneness to conflict is suppressed.

The change in the traditional world view (and associated traditional consciousness) occurs when the existing world view loses its adaptive properties or when the main cultural theme of ethnos loses its meaning (relevance). Then the new cultural constants are transferred to real (relevant in new conditions) objects and there occurs crystallization of the new traditional consciousness of the ethnos around the new significant objects. However, the basic paradigms remain unchanged: general characteristics of cultural constants, a mode of their interrelations and a balance between the "good" and the "bad", the "images of oneself", including ideas about groups capable of performing concerted actions, principles of action and interaction of people in the world. The mechanisms of such transformation can be different.

- Evolutionary change in traditional consciousness. As a result of a gradual change in the value orientation or a change in the external and internal cultural, political and social conditions of the existence of an ethnos, the objects of transfer are adjusted. This adjustment is not recognized by the traditional society. To an external observer, the substitution process is represented as accentuation of certain fragments of the old tradition, adoption of cultural or ideological innovation and disappearance of a number of features previously inherent in this tradition.

The process of substitution turns out to be a result of the activity of the carriers of self-responsible consciousness within the traditional society. However, the continuity of such reconstruction of the tradition is only apparent. Despite the fact that the changes in the tradition accumulate gradually, the consolidation of new transfers (and, consequently, the crystallization of a new cultural tradition) occurs as a result of a more or less obvious social distemper that shatters the old ties and makes the system mobile. Then the carriers of self-responsible consciousness inform society of a new model. Thus, new "names", meanings are attached to the system in times of crisis of self-identification.

- Change of internal alternatives in the traditional consciousness. Since several types of traditional consciousness can be formed within the framework of a 
single ethnic culture on the basis of different value orientations, the struggle between different internal alternatives of traditional consciousness will inevitably take place in the ethnos itself. It is usually waged between the carriers of self-responsible consciousness, and from time to time the broad strata of people join this struggle. The victory of one or the other party causes a massive movement of public resources from one alternative to another. Such victory can be determined both by cultural and political circumstances that create more favourable conditions for representatives of one of the alternatives than for the other (and, as a rule, the number of adherents of the latter is being sharply reduced), and by strengthening of the desire for another definite value orientation among members of the ethnos.

The transition to another alternative is connected (as in the previous case) with a certain state of social distemper, a temporary loss of adequate self-identification. But the mechanism of changing the tradition is different here. When the cultural and historical conditions of the ethnos are changed, there occurs some sort of "saturation" of one of the alternative traditions, and, on the contrary, blocking of others, including the one that was formerly dominant. Then the latter lose their adaptive properties (for example, the image of a "defender" is blurred). Such a state can be the beginning of a period of distemper. Under these conditions, with the increase of the ethnos's attraction to other specific value dominants, an intra-cultural group, a carrier of the fading alternative, nevertheless continues to exist in an almost unchanged form until the period of the obvious beginning of distemper. And the group of the fading alternative is not able to bring the ethnos back to the initial state (to the state preceding the distemper) because the number of carriers of self-responsible consciousness inside this (weakening) alternative is less than critically necessary for stabilization. But the way out of distemper is possible in the framework of another alternative, in which, on the contrary, there is a concentration of the carriers of the corresponding selfresponsible consciousness (which is the ethnos's choice of this or that alternative).

- Change in traditional consciousness caused by a catastrophe. The change in the traditional consciousness of the ethnos as a result of a catastrophe, when the previous cultural world view begins to sharply contradict reality and there are no alternative traditions with great adaptive properties, as a rule, occurs under temporary deficit conditions. Ethnos should create a completely new cultural tradition, since such a state of distemper threatens the complete breakdown of ethnic culture.

In this case, of all the cases of transformation under consideration, the most evident is the manifestation of the spontaneous self-structuring of ethnos, which can be 
called one of the most amazing phenomena in the life of the ethnos. The ethnos that is not capable of spontaneous self-structuring soon dies under historical cataclysms. And on the contrary, the mobility of the restructuring mechanism ensures the "vitality" of the ethnos. The element of its spontaneous self-organization that is the most simple and often found in the ordinary conditions of life of the ethnos represents unconscious reproduction by members of the ethnos at the time of an external threat of a set of actions, reactions and feelings that gave them the opportunity in the past to experience a similar situation with minimum losses. In an extreme situation, the ethnos, first of all, reproduces the usual reaction to danger and tries to perceive what is happening within the world view it has accepted.

But if the pressure or threat from the outside world becomes so great that reality no longer fits into the world view interiorized by the ethnos, then the traditional consciousness of the ethnos, in all its available modifications, loses adequate adaptive properties and begins to disintegrate. Although the ethnos retains a set of cultural constants embedded in its unconscious, its transfers to the objects and subjects of the external world are hampered. Then the conflictual nature of the ethnos in relation to the external world gets more acute, the reality seems to be such that it is impossible to impose any projection of cultural constants on it, and thus adapt and balance it, establish adequate dispositions and correlations of forces between the sources of the "good" and the "bad". In order to preserve its identity, the ethnos must find an acceptable transfer option, and, for this, it must crystallize a completely new picture of the world that has no analogues in its past around its cultural constants. Crystallization of the new world view leads to reorganization of the whole life of the ethnos. Unable to change the world in such a way as to be able to project its set of cultural constants on it using the usual transfers, the ethnos changes the principles of its organization in such a way that it is possible to establish the necessary balance (that is, to ensure adequate transfers). There are two possible ways here, and, in part, they act simultaneously, nevertheless, one or the other prevails in each particular period, but different ethnic groups tend to prefer one of them.

The first way, we called it conservative, leads to the formation of such an intraethnic organization that would establish additional barriers between the ethnos and the world, allowing the majority of the ethnos to ignore changes in the conditions of their historical existence, as if everything in the world remained the same. This organization is formed as a result of the stratification of the ethnos on the basis of a special stratum structure of the intra-ethnic tradition. The stratum of ethnos that carries the weight 
of external contacts creates its own version of modification of the cultural tradition. Because of its value system, it is unacceptable for most people, but it provides external communication. Value exchange between strata (separate intra-cultural groups) representing different intra-ethnic traditions, is minimal. Though society seems to be permeated with social institutions (at the same time, being transfer objects) that are especially significant in all modifications of the tradition (although their interpretation in the context of different variations of the ethnic world view may be different).

The second way, we called it creative, is connected with finding new objects for transfer, which, however, requires a significant if not complete, change in the way of life of the ethnos and establishment of special new public institutions, which enables the transfer to gradually become possible and adequate.

Self-structuring of an ethnos occurs as interaction of intra-cultural groups having different value orientations. Although their actions are objectively aimed at restructuring the internal organization of the ethnos and creating new public institutions that correspond to the newly occurred transfer, they cannot recognize it. We cannot say that at first the world view is formed, and then the reality is rebuilt so as to correspond to it. These processes are parallel. The world is not "recreated" in accordance with the new ethnic world view, and being already rebuilt on the basis of new transfers, is recognized as adequate to the ethnic tradition.

Let us consider the above said by an example of formation of Yerevan as a sociallypsychological community in the middle of the $20^{\text {th }}$ century ${ }^{1}$.

Since the process of self-structuring requires tremendous tension from the ethnos, the condition for its success is the presence of a greater number of carriers of self-responsible consciousness within the ethnic community than in the usual stable time (though crisis and tragic epochs favour the increase in the number of such people). However, there is one extremely important circumstance here. For the normal course of the spontaneous selfstructuring of the ethnos it is necessary that the carriers of self-responsible consciousness do not become outsiders in their traditional society (which is a frequent phenomenon in times of crisis), that they voluntarily agree to experience a tragic and troubled era with their people. The withdrawal of the carriers of self-responsible consciousness from the

There is very little scientific literature on Soviet Yerevan. Some ideas about its realities are given by the works of S. Fehlings (2015), (2016), and Shakhnazarian (2013), Ter-Ghazarian (2013). The problems of Armenian identity are studied in the articles of Iu. Antonian (2011), K. Cavoukian (2013), M. Lehmann (2015), M. Mazinani (2013), J. Laycock (2012) and T. Mkrtchan (2015). Psychology of Armenian-Turkish relations that are difficult for Armenians and significant for the establishment of Yerevan is mentioned in the works of S. Kasbarian and K. Oktem (2014) and S. Hirs (2013). 
traditional society leads to the destruction of society, and then, perhaps, to the erosion of the system and a set of cultural constants of the ethnos.

\section{The phenomenon of Yerevan}

The phenomenon of Yerevan begins with the fact that the unique existence of this city has not attracted any attention so far. However, it is not surprising. Uniqueness of Yerevan can hardly be expressed with the help of standard indicators used by urban planning experts, establishing typological similarity and distinction of different cities.

One of the major industrial centres that grew up in the Soviet period in the last decades, one of the capitals of the former Soviet Union... What was interesting was the monoethnicity of the city with population of million people, which breaks down all the statements of sociologists that unequivocally connected urbanization with the polyethnicity of large cities considering it as its obligatory accompaniment. But the further it developed and Yerevan expanded its borders, the more homogeneous its environment appeared. Armenians are almost the only nation that lives in this city.

The Armenians of Yerevan at the end of the Soviet period seemed to be already hereditary townspeople, an urbanist people, long accustomed to urban civilization. And Yerevan looked very solid, organic, with its style of relations, its very dense, traditional and conservative environment. It was like an old city, in which traditions have not yet been destroyed: as if in other cities the process of disintegration of traditional relations was going faster, and in Yerevan it is going slow, but soon it will happen. ${ }^{1}$

1 In Yerevan, social processes have been going not quite in the usual way. Urbanization is usually accompanied by the destruction of traditions, makes the social environment more open and tolerant of diverse values and patterns of behavior. In Yerevan, this process is reversed. As the city grows, as it is industrialized, the social environment of Yerevan becomes more and more closed and conservative. According to observations of sociologists, new patterns of behavior, etiquette, rituals that were unknown to Armenians earlier, but were quickly perceived by the entire population of the city, have been developed in the Armenian capital. It is noteworthy that "the representatives of mental labor and the age group of 18-29 years old are more staunchly adhering to these norms than the representatives of physical labor and older age groups - my remarks, S.L." (Karapetyan, 1986a: 30). In the inter-censal period of 1959-1979, the process of family consolidation in Yerevan and in the republic as a whole was recorded (Karapetyan, 1986b: 126). As a result, according to the 1989 census, the average Armenian family had 4.7 people, so Armenia and Yerevan were the leaders on these indicators among all the non-Muslim republics of the former Soviet Union and their capitals. Moreover, the enlargement of an average family took place in parallel with a very significant drop in the natural growth of the urban population: the growth rate decreased from $27.4 \%$ in 1960 up to $15.1 \%$ in 1987 , and $8.9 \%$ in 1988 . This means that the average enlargement of an Armenian urban family was not due to the natural growth, but to the complication of its structure. This process is also the reverse of those that are believed to accompany urbanization and industrialization. While still small, the Armenian family, nevertheless, tends toward complication of its internal structure, in order to become a family uniting two or three generations. In Armenia, not only the complex families 
But no. Yerevan is a brand new city, very young, despite the dizzying age of Yerevan-history, legendary Yerevan. Yerevan that we see at the decline of the USSR is only 10, 15, 20 years old. For the last centuries in its place there was a typical provincial eastern city, the administrative centre of the first Erivan khanate run by the Persians, then the Erivan province subordinate to the Russian administration. "Yerevan was a backward, ordinary Asian city with narrow streets with houses built of bricks and small round stones... The city was spread over a vast territory, but was not crowded" (Akopyan, 1979: 123). Even by the beginning of the $20^{\text {th }}$ century, the city's population did not reach 30 thousand people.

This is a starting point.

The present Yerevan had no analogues in Armenian history. In different centuries there were several great Armenian cities, such as Dvin, Ani, Kars... - but they were functionally quite different - the capitals of lands that were sometimes quite extensive. These cities were their adornment, glory and pride. But they were precisely the centres of the lands inhabited by Armenians, and not at all the main focus of the Armenians' life. No centripetal forces gathered Armenians from all over the world. Then the Armenians lost their lands, and those who lived in cities lived in foreign cities, in foreign capitals, in many capitals of the world. Demonstrating their phenomenal vitality, almost without mixing with the local population, they quite organically fit into the life of a foreign city, adapting, if possible, a foreign city to themselves. They got accustomed to foreign capitals, not having their own for a long time. "The recognized leading centres of Armenian creative forces were Constantinople and Tiflis, where the Armenian commercial and industrial capital was concentrated. Here was a large part of the intelligentsia... The Armenian colony of Calcutta was of special importance... Smyrna (Izmir) was a large centre of Western Armenians. Baku has been such a centre for the Caucasian Armenians since the late 19 $9^{\text {th }}$ century" (Erkinyan, 1981: 11). Large Armenian colonies were in Moscow, Astrakhan, Saint Petersburg, Crimea, Paris, Geneva, Vienna, and Cairo...

In the era of rapid industrial development, Armenians, who were well-known as clever and talented money-makers, also invested their money in foreign capitals, foreign cities; in the Russian Empire it was: Baku, Tiflis (where the Armenian capital

rate is relatively high, but there is also the lowest percentage of single people and childless couples among the capitals of the former USSR (Karapetyan, 1986c: 80-81). And finally, there is the smallest percentage of divorces in the country. An Armenian family of the post-Soviet times, although it is of a small structure, had exceptionally strong ancestral ties. 
was predominant), St. Petersburg, Moscow and the cities of Central Asia... The cities of Eastern Armenia received virtually nothing. "Armenian manufacturers of Transcaucasia and Moscow, with the help of Armenian wholesalers, supplied fabrics, oil products, sugar, haberdashery, dishes and other consumer goods to Central Asia... But merchants have not imported anything to Transcaucasia...” (Grigoryants, 1981: 7). Armenians, mostly from Karabakh and Zangezur, built industrial facilities, bridges, railway depots, etc. in Central Asia. The money was invested by Russian or anyone else - the company Moraviov and Co, the Yaroslavl Manufactories Association, Alekseev from Moscow, Pozdnianskii from Lodz - but only very rarely by the Armenians themselves (Parsamian, 1972: 47).

And the peasants who became poor went to Tiflis, and even more often to Baku in the need of new sources of income. There the peasants "found job in the oil industry, joined stonecutters, carpenters and carpenters" (Kocharyan, 1925: 36). And eventually Baku obtained the features of an almost Armenian city.

Even the rapid process of national revival that began from the second half of the $19^{\text {th }}$ century, somehow cannot be connected with the territory of Eastern Armenia, at least, it does not lead to any noticeable repatriation. Tiflis is one of the centres of the national revival of Armenians. If in the middle of the century most Armenians living in Tiflis did not speak their native language, by the end of the century almost all of them began to speak Armenian, to read Armenian newspapers, to monitor politics. Here, Armenian educational institutions were opened, national clubs were established, and Armenian newspapers were published (Kanadpev, 1902: 165-166).

And what about Erivan, Alexandropol, Goris, Gavar and Shusha?

Eastern Armenia remained underdeveloped industrially, it was more agrarian. The largest Armenian city, Shusha, "a beautiful, well-maintained city, populated mainly by rich Armenians", was a city "for recreation and entertainment" (Kocharyan, 1925: 27). Energetic manufacturers and merchants did not even care for the fact that there was no railway here. Shusha, the ancient capital of Artsakh (Nagorno-Karabakh), became deserted. But almost all the Armenians of the Transcaspian region and Turkestan, not to mention Baku, came from Nagorno-Karabakh.

Yerevan as a huge city began to form almost right in front of our eyes... The main increase in its population falls on the 50's-70's. These are the years when other cities of the USSR are growing just as rapidly, involving former peasants, inhabitants of small towns, and a wide variety of migrants. This is the time of the great migration, mixing of peoples, and establishment of huge international centres throughout the country... 
People from all over the Union come to Yerevan, but only the Armenians. Part of the population of Yerevan is from Armenian villages, the other (large in number) is migrants from large cities and capitals of other union republics, primarily Georgia and Azerbaijan. In addition, thousands of Armenians from foreign countries. So different flows: peasants from remote mountain villages, people from Tiflis, Parisians, plus "old Yerevanians..." Spontaneously, something completely new, unprecedented is created a huge national centre of unplanned and almost unregulated gathering of the ethnos into an organic and natural community. If you take into account the tiny size of the territory of modern Armenia - the national city-state has practically grown. Then, inevitably, certain questions come to mind: why did Armenians from all over the world come to Yerevan? Why did only Armenians come? What was Yerevan like as a psychological community?

\section{Those living in foreign empires}

Did the Armenians need their own national centre for the time being? It seems that nothing in their behaviour indicated this.

As for the tendency of the settlement of the Armenians in the $18^{\text {th }}-19^{\text {th }}$ centuries, it was more centrifugal than centripetal. The Armenians settled in places where religious and national oppression was weaker (this was the reason for the permanent migration from Turkish Armenia to Russian) or where there were greater opportunities for applying their energy.

The Armenians accepted the position of people living in foreign empires quite easily. Moreover, they actively participated in the state life of those empires in which they lived, sought top government positions, for example Loris-Melikov (served as the Minister of the Interior) in Russia under Tsar Alexander II. They defended their de facto independence by economic means as the nation with obvious entrepreneurial skills, and peacefully got along with their neighbours. For the time being, even in the Ottoman Empire, the Armenians had the reputation of a calm, loyal nation who, unlike the Greeks and the Slavs, did not express special separatist demands. This was so until, for political and economic reasons, they were not subjected to particular harassment and persecution in the Ottoman Empire (beginning from the second half of the $19^{\text {th }}$ century) or in the Russian Empire (at the beginning of the $20^{\text {th }}$ century, during the period of violent russification during the rule of Prince Golitsyn in the Caucasus).

The Armenians, who at one time not only voluntarily became part of the Russian Empire, but actively pursued this for more than 150 years, and then helped Russia 
to seize Transcaucasia with arms, willingly went to the Russian civil service. They constituted "the main part of the officials in the Caucasus, officials of railway stations, clerks, record keepers, and in general, minor intellectuals; they also form a significant number of Caucasian lawyers and doctors. There are the Armenians in the Caucasian administration and troops and have a great influence on affairs. Sometimes they appear in the positions of governors, state property managers. It is not unusual to meet the Armenians among officers, colonels and generals. They participated in all Russian wars in the Caucasus and were distinguished by their courage" (Priemskii, 1907: 7).

Nevertheless, as soon as Christians were allowed to become state officers in the Ottoman Empire, the Armenians took advantage of this opportunity.

The reaction of the Armenians to the collapse of hopes for the autonomy within the Russian Empire, whose projects at the Russian court at one time were accepted quite favourably, was almost completely indifferent (unlike the Georgians' one) and they accepted the situation with ease. They demolished social injustice quite easily, but what they really could not bear was when they were oppressed as the Armenians. In any conditions, in any empires, they managed to preserve full cultural autonomy.

The Armenians almost completely lacked any social hierarchy. There was no nobility, with the exception of the regions of Karabakh and Lori. (This refers to the period from the late Middle Ages, when the Armenian statehood was completely lost.) "The commercial bourgeoisie had very little to do with the peasant masses associated with landowners. In the Armenian regions (with the exception of some districts), the land inhabited and cultivated by the Armenians belonged to the Turkic landowners" (Khudadov, 1926: 40).

The main force uniting all the Armenians was the church, which enjoyed some political independence. In the literature, we even find the opinion that the entire political life of the Armenians "receives general guidance from the Armenian theocracy" (Berezovskii, 1908: 8). The church was one of the most important bases for the selfidentification of the Armenians. For long centuries, it retained its complete isolation from other Eastern Christian churches and to a large extent impeded both the cultural interaction of the Armenians with neighbouring nations and assimilation. Perhaps this self-isolation of the church had led to the fact that in those times when for other peoples ethnic self-identification was of little significance compared to cultural, state and religious self-identification, the Armenians identified themselves as a people, an ethnic group. Religious identity coincided in this case with the ethnic one and caused 
the latter almost completely. The constant and very clear opposition "Armenians vs. non-Armenians" became the fact of their everyday life.

Nothing reveals cultural autonomy (and self-isolation) of the Armenians, as much as their constant and almost obsessive dreams of "the past and lost paradise". The poem "Krunk" ("The Crane") by Nahapet Kuchak, a poet of the $16^{\text {th }}$ century, is often performed to this day as a popular folk song:

I don't have any holidays, only some humdrum life.

I've been pierced through with a turnspit,

I've been burnt in the fire.

Though not the fire burns me, but memories of the past.

"The memory of the past" is one of the most important components of the consciousness of the Armenians. The memory of the former greatness, of the ancient Armenian statehood, of the golden age of the Armenians had a clearly eschatological, almost religious colouring. The ideas associated with this dream did not include the intention to implement them "here" and "now", but only the hope of doing it "someday".

In the $11^{\text {th }}$ century legend "About Good Times" it is said about the ideal Armenian state: "There will be no misfortune in the country, / There will be no grief and enemies, / No thieves and robbers, / Love and joy will come, / Joy and exultation, / Lies will disappear, / And the truth will increase, / And the whole country will be filled with kindness. / Where is hell? It is gone. / Where are the enemies? They are defeated. / Where are the enslavers? They are expelled. / They are destroyed, they are nowhere to be found. I And no one in the world remembers them. I And then the Armenian people dispersed all over the world / Will gather in their country, / And the Armenians will come from everywhere, / From where they were expelled / By the wicked, rotten hordes of tormentors" (according to Khechumyan, 1983: 54-55). It is obvious that these verses speak of an earthly paradise; in form they copy the New Testament text about the heavenly heaven. The "Elegy" by Nerses Shnorhali (the $12^{\text {th }}$ century) is about the same: "My sons who are gone, / Who are now far away from me, / Will return in chariots, / Harnessed by horses, / Those who were dispersed all over the world / Will return" (according to Khechumyan, 1983: 55). This is so far only a dream of some unclear future. It was to become a guide to action only in the $20^{\text {th }}$ century.

Therefore, the Armenians showed almost complete indifference to political autonomy, but cultural independence was almost sacred for them. During the mass 
slaughter of the Armenians in the Ottoman Empire, they were usually offered a way out: to convert to Islam. Those who renounced Christianity were not killed by the mobs, although they still robbed their property. But this way out was used only by a few.

The resistance of the Armenians to the attempt of their violent russification undertaken by the Caucasian administration at the very beginning of the $20^{\text {th }}$ century was also quite fierce, when it was primarily expressed in the confiscation of property of Armenian churches and the closure of Armenian schools. The response of the Armenians resembled the policy of "civil disobedience".

"The church property that had been taken away, except for cash, of course, immediately turned into dead capital. If it was a house, they did not hire it; if it was land, they did not rent it. The Armenians trying to take advantage of one or the other were warned, and it worked. The clergy with the Catholicos at the head refused to receive interest from the amounts managed, preferring to starve and get by on the little money collected by its parishioners than to touch the money offered by Russian officials. This was not enough. They boycotted government agencies. Rural and county courts ceased to function in those places where the Armenians lived. The society used its own courts organized by the Dashnaktsutyun committee. In a short time, these public courts acquired such authority that Muslims living in the neighbourhood also began to appeal to them" (Dzhivelegov, 1906: 29-30).

Another subject of the boycott became Russian schools. The Armenians did not send their children to them, and instead of the closed government Armenian schools, new ones were arranged, the existence of which the authorities did not know about. The teaching programme was brightly national. There were many such schools: in the Karsky region alone there were about sixty" (Dzhivelegov, 1906: 31).

Of course, the Russian government regarded such actions as an attempt of separatism, which was subject to harsh punishment. Indeed, a grand process was started, which was aimed at teaching a lesson to all the other peoples of the empire. However, it went nowhere. No separatism was identified. As reported by the then governour of the Caucasus, Count I.I. Vorntsov-Dashkov, "any attempt to accuse the Armenian people of separatism faces real facts, which prove, on the contrary, the devotion of the Armenians to Russia. Therefore, contrary to my notifications, the ambitious process of the Dashnaktsutyun party launched by prominent capitalists and public figures in insufficiently informed St. Petersburg, which was supposed to prove revolutionism of a whole nation, and started with an effective, simultaneous arrest of a thousand of the 
Armenians throughout the Caucasus, without letting me know, came to nothing. About 30 Armenians were sentenced to different terms of punishment" (Vsepoddaneishii otchet... 1913: 7).

As soon as the active attack on the cultural autonomy of the Armenians was stopped, the whole confrontation disappeared. The Armenians again became very loyal citizens of the empire. According to Vorontsov-Dashkov, "the outbreak of the nationalist movement among Russian Armenians, accompanied by terrorist acts against representatives of the authorities, was caused by the seizure of the property of the Armenian church, but this movement immediately ceased to exist and, one can say, irrevocably, as soon as Your Majesty decided to show the royal mercy by returning the church to its property" (Vsepoddaneishii otchet... 1913: 7).

What was really amazing in this act of "civil disobedience" was the speed with which the Armenians were able to organize, and then the speed of disintegration of structures created at a critical moment, as long as they had served their service. The Armenian publicist A. Dzhivelegov wrote: "In order to understand how the peaceful people got organized so quickly, one must keep in mind the activities of the Armenian Droshakist Committee [i.e. Dashnaktsutyun - author's note]" (Dzhivelegov, 1906: 35). However, the activities of the Dashnaktsakans in the Transcaucasia began after the Russian administration began to close schools and confiscate church property, and was a reaction to these measures. "In 1903, Dashnaktsutyun was forced to shift its attention from Turkey to Russia," writes the party's historian (Atamyan, 1955: 17). Dashnaktsakan cells, like mushrooms after the rain, grew in every Armenian village. Armenian capitalists donated huge sums to the party. In the cities, the Armenian workers unanimously left the ranks of the Social Democrats and "almost all have become the members of the Droshakist Committee" (Dzhivelegov, 1906: 15). "There was hardly any Armenian who did not consider himself a member of the Dashnaktsutyun" (Vadin, 1907: 32). With the end of the Caucasian events of 1903-1907, with the appointment of a new governour of the Caucasus, who led a policy loyal to the Armenians, Dashnaktsutyun abruptly lost its popularity and turned into a completely private party with a programme close to social democracy.

Afterwards especially suspicious individuals from the administration and publicists for a long time looked for traces of a secret Armenian conspiracy, but it was absolutely in vain. The nation was living their peaceful life, cultivating bread and grapes, shepherding, weaving carpets, doing business, serving in state institutions, most of them could not tolerate politics, and had forgotten the past years as a bad dream. 
Everything that had happened turned out to be a manifestation of the psychological defense mechanisms of the traditional consciousness of the Armenians, their ability to instantly organize themselves in response to external pressure.

It is not a coincidence that we have focused in such detail on one of the episodes, far from the most significant, in the history of the Armenians. When we touch directly on the topic of the formation of Yerevan, we will discover the same mechanism of emergency self-organization.

As for the political demand of the Armenian statehood, then it was not there. In Turkey, the Armenians demanded only a certain autonomy of the Armenian vilayets and the appointment of Christian governours in them, and in Russia, a certain autonomy for the whole Transcaucasia, which was ethnically diverse, with its general dependence on the Russian Empire. Although the idea of independence of Armenia periodically appeared in the speeches of leaders of Armenian political parties, but it was not at all popular among the people. It penetrated into the minds of the people, rather, not as a political, but as a cultural idea; its source was not so much a political struggle for self-determination, but cultural and educational work: for example, as soon as an opportunity to spread education appeared in Turkish Armenia, many young people devoted themselves to teaching in national schools. Moreover, when as a result of the Russian revolution, the Transcaucasia was de facto separated from Russia, Armenia was not in a hurry to declare its independence, its representatives entered the Transcaucasian Seim, and when it collapsed, Armenia was the last to adopt a declaration of independence after Georgia and Azerbaijan. As a matter of fact, Armenia had nothing more to do.

\section{The myth about Yerevan}

At the end of the $19^{\text {th }}$ and the beginning of the $20^{\text {th }}$ centuries, a number of global events took place in the history of the Armenian people. First, since the 1890s, a number of political parties with a national programme had been operating in the Armenian environment (primarily among peasants), and the fidayi movement (hajduk) emerged. Secondly, from the end of the $19^{\text {th }}$ century a number of unprecedented Armenian riots began, which ended in 1915-1923 with almost total extermination of Western Armenians. Thirdly, there was some hope for the unification of Eastern and Western Armenia under a softer Russian protectorate, perhaps even with a certain degree of autonomy. The Russian army, in the ranks of which 7 Armenian regiments are fighting, liberates the Eastern vilayets of Turkey ... 
Then the events were developing with very fast: the revolution in Russia the withdrawal of the Russian army from Transcaucasia - the convocation of the Transcaucasian Seim - its collapse - unexpectedly aqcuired independence the proclamation of the Armenian Republic - fighting between the republics of Transcaucasia - the Northern peace treaty according to which the border of independent Armenia is outlined in such a way that the reality seems to begin to exceed the wildest dreams of the Armenians, - the hope for the help from other states - the disappointment in it - the war with Turkey - Turkish invasion of Western and some parts of Eastern Armenia - the League of Nations's refusal to help Armenia - the humiliating Alexandropoulos peace - the attack of the Red Army - the transfer of power to the Bolsheviks by Dashnaktsakans - the proclamation of the Soviet power - the agreement between Russia and Turkey, which recognizes the sovereignty of the latter over a number of districts, previously included in the Russian Empire and inhabited by the Armenians - the Lausanne Peace Conference, where the world community recognizes the legitimacy of the Russian-Turkish Treaty and where the phrase "Armenian matter" is never even mentioned. And that is all...

For the next seventy years, the Armenian history seems to be standing still, nothing seems to happen anymore ... Meanwhile, it is during these years when Yerevan emerges.

Sometime in the 1920s, the architect Alexander Tamanyan drew a plan of the city, and then everything seemed as to happen by itself. The Armenians started to gather in Yerevan and defend their monoethnic integrity. Traditions and the system of relations were being created naturally forming a very dense environment of Yerevan.

It seemed that Yerevan should have become one of the dozens of chimera cities generated by the Soviet giantmania. Instead, it turned out to be a gathering point for the Armenians scattered around the world. And it also happened somehow naturally.

There was an opportunity to return home, and people returned. "My last address is Yerevan," "I am no longer an exile," repatriate poets called their collections of poems: "This day was a day of miracle, and I woke up in Yerevan."

However, we cannot fail to see that these facts themselves, their spontaneity and naturalness indicate that they are only an outward manifestation of deep metamorphoses in the minds of the Armenians. What happened? How did it turn out that the dream about the Armenian state became a guide to action?

There is probably no nation in the world that would not have their heroic epic. At some particular moments, it may inspire some individuals to great deeds - but 
this does not happen often. Mainly, the epic is kept in the minds of the people as beautiful legends that are pleasant to remember and re-read ... The Armenians, of course, also have such a heroic epic, in particular, legends about David of Sasun. But the epic, which calls for action, is of a completely different nature. This story is about the glorious history of the people, but addressed directly to a contemporary pointing out to the enormous gap that lies between the glorious deeds of the ancestors and a miserable existence of the contemporaries.

The initial merit in the creation of the modern Armenian epic belonged to the leaders of national groups and parties, and mainly to writers and publicists of the late $19^{\text {th }}$ century, such as Grigor Artsruni, Raffi, Leo, Mkrtych Khrimyan, who actively propagated the Armenian history placing emphasis on its heroic aspect. Self-consciousness of the Armenian people is performing a rapid transition from the focus on national survival and simple preservation of national identity to the sense of greatness of the nation and the exclusivity of its destiny and historical mission. In the words of a modern researcher, Armenia, many times defeated, willingly exalts its history, gives it a bright image of martyrdom. Dismembered, devastated, subjected to persecution, excluded from the number of states, it creates its history on the verge of a golden legend. It has giants and warriors who break the bones of lions and break ribs of bulls. Leo, who wrote the multivolume history of the Armenian people; the author of the action-packed historical novels Raffi, publicist Gevorg Artsruni, and Catholicos of All the Armenians Mkrtych Khrimyan create a national myth about the Armenian hero, warrior and martyr for the truth. Through books, newspapers, messages of Armenian priests, this image penetrates into the consciousness of the Armenians, above all those belonging to the educated layer, causing them to fight for the liberation of their whole country, to fight under the auspices of the Russian Empire. Sometimes this led to early decisions to break free from the paws of the Turks at any cost.

The Russian-Turkish war of 1878-1879 largely provoked these actions. More precisely, not the war itself, but its artistic description in the novel "Hunt" (Madman) by Raffi. This book, in which intellectual revolutionaries, overcoming the inertia of the masses, inspires the people to struggle for the freedom of Western Armenia, has become a peculiar Armenian variant of the famous Chernoyshevsky's "What is to be done?". The protagonist - Vardan - became for the generations of Armenian youths the same as Rakhmetov was for the Russian populists, and the novel ended with a replica of the "fourth dream of Vera Pavlovna" - Vardan's dream, in which a picture of future 
Armenia, where communal socialism is established, and Kurds and the Turks, under the influence of education, assimilated with the Armenians ...

Without knowing it, Raffi set forth a thorough programme of action for the Dashnaktsutyun party, created in 1890 by a group of Armenian students. Having absorbed the heroism of the historical myth created by the older generation of journalists, the Dashnaks set two goals for themselves: to convey this myth to every peasant in Eastern and Western Armenia by communicating with the people and inspire the whole nation to fight with the Turks, finally achieving a fair resolution of the agelong "Armenian matter". In the actions of young revolutionaries, especially at first, there was more romance and enthusiasm than real knowledge of popular life and thoughtful politics. The Dashnaks by means of propaganda, threats, and even the use of force forced to join the ranks of the anti-Ottoman movement and the Parisian bankers, and Istanbul merchants, and Cilician peasants. "Unfortunately, cautiousness and prudence were not the virtue of the Armenian leader," one of the movement's participants admitted later. In Armenian literature, an image of the Dashnak was formed, driving a cow out of the yard with a Mauser in his hand, in order to buy a rifle for a peasant with the money from the sale and send them to fight with the Turks.

For the Dashnak revolutionaries, the liberation from the power of the Turks was the end in itself. They wanted one thing: to cause the intervention of the powers in Armenian affairs. Therefore, they did not care who they were dealing with, Russia or its antagonist, England, which sometimes caused both bloody tragedies in Turkish Armenia and cooling of the relation to the Armenians in Russia.

Though let us return to the provocations of the revolutionary dreamers who aroused genuinely popular forces, which later turned into even more blood. Almost everywhere in Western Armenia, Turkish riots met fierce resistance, and in the mountains the fidayi (hajduk) partisan movement was developing. Every Armenian knows the names of Gevorg Chaush, Serob Akhpyur, Arno, Murad, and finally, the man of legend Andranik, the son of a shoemaker, who started his way from organizing the selfdefense of the Armenians in Sasun, and who finished it as a general of the Russian Army commanding the Cossack corps, after the collapse of the Russian Empire, who defeated the Turks in Nakhichevan ...

The circle was closed: the national heroes created by the imagination of writers and publicists turned into living people in order to become a myth once again. A great number of legends and sayings of Andranik, Gevorg Chaush and others go around 
Armenia and form instructions and teachings to the Armenians, the basic moral values of the people are formulated. However, the Dashnaks themselves, existing as a party so far, split in the popular consciousness, into one of the political parties with a socialist bias and the All-Armenian heroic movement.

The beginning of World War I put the question point-blank. The Turks addressed Dashnaktsutyun with a proposal to raise an anti-Russian revolt in the Transcaucasia and to make a "fifth column" there. For this, the Turks promised the Armenians the power over the whole Transcaucasia after the victory. At the same time, the Russian command turned to the Dashnaks, with a call to start a rebellion in Turkish Armenia and, it seems, did not promise anything, at least in writing. The Turks were given the answer no, while the Russians received the answer yes. Then there was a revolt in the border Vansk region, and sending of volunteers to the Russian command. Although the Russians did not ask for the latter, but in the end, seven Armenian regiments were fighting on the Russian side. The Armenians wanting to help Russia in every possible way, drew fire on themselves. During this period, even the policy of Dashnaktsutyun, these Armenian Socialist Revolutionaries, is purely pro-Russian. Every single bet was made on Russia. Here, unlike the Russian counterparts in socialism, there was no defeatism at all.

Heroism by the will of historical destinies, turned into a tragedy. The government of the Young Turks makes a final decision on the Armenian matter: "To evict all Armenian citizens of the Ottoman Empire older than five years from the cities and kill ...", the Turkish Minister of War Enver Pasha orders on February 27, 1915, - all Armenians serving in the army should be isolated and shot". In this monstrous slaughter about a million of Armenians were killed. The rest became refugees. Others, God knows how, got to European countries, and then to America, and some were protected by the Russian army, and then managed to escape to Russian Armenia. Refugees were concentrated in Yerevan, whose population then began to increase quickly, and its administrative significance started to grow.

The genocide itself was a tragedy, but not yet a psychological breakdown for the Armenian people: the Armenians fought on the side of Russia and hoped to get even with the Turks in full. But in 1917, Armenia suddenly loses its patron. The empire collapsed, and in May 1918 the Dashnak government announced that it was "forced to proclaim independence" of the Armenian Republic. This happens against the background of the Turkish invasion of Eastern Armenia, which almost ended in the complete destruction of the Armenian people, but turned into a glorious victory of the Armenians in the 
Sardarapat battle. At this time, the role of Yerevan comes to the fore - the government of independent Armenia, almost all Dashnak, led by Dro, is located in Yerevan.

Thus, "Dashnaktsutyun provided one of the most important prerequisites for the birth and development of national identity and solidarity - the cult of the national hero" (Atamyan, 1955: 67).

At the same time, another purely pragmatic political trend was formed in the same years, represented by the Ramkavar-Azatakan party of major industrialists and bankers, who proclaimed in their programme a complete rejection of any armed struggle that brings new misfortunes to the Armenians, complete submission to any political power and concentration of all forces on cultural and educational work. For the time being, this new "tradition" was not very popular.

Therefore, two opposite alternatives emerge for the Armenian people, which could be simply called heroic and pragmatic.

However, in the twenties, both Dashnaktsakans and Ramkavars leave the current political arena in exile and continue their activities only in the Diaspora, having few opportunities to directly influence the course of events in Soviet Armenia. Nevertheless, new political traditions that have appeared, continued to exist. Next, we will try to describe the specifics of their implementation, and now let us only note that they were implemented in a completely unexpected way. Firstly, because in practice they were merged together. Secondly, because the main burden of their implementation fell on ... the Communists. Thirdly, because of the RESULT of their implementation. Fourthly, because this implementation took place in an unusual way. And fifthly, because it was not accompanied by any explicit ideologizing.

\section{Objectification of the myth}

The Armenian Genocide in the late $19^{\text {th }}$ and early $20^{\text {th }}$ centuries and a number of events that followed it (a series of post-war peace conferences where the Armenian matter was considered or, later, was not considered) were a tremendous shock for the Armenian people. Moreover, it is still unknown what shocked them more: the evildoings of the Turks, the huge number of victims, exceeding a million people, the mass exodus from the historical Armenian lands or the blatant injustice of the peace conferences that followed the world war, where the evil was not condemned, where the Armenians were denied not only their right to their own historical territory, not only in the right to at least the "national centre" within Turkey, not only in material compensation for the plundered property, but even in moral support. They simply 
waved off the Armenians. By that time, the world had managed to forget about the genocide, but for the Armenians it became even harder than the genocide itself. They lived scattered in different countries, often even hiding their origin (although they were not persecuted) and who were convinced of the total injustice of the world. A number of terrorist attacks against Turkish diplomats gave very little consolation. The degree of conflictness of the Armenian consciousness continued to grow. It could be expected, as in the case of the Caucasian events of the beginning of the century, that in the Armenian environment a certain internal structure will arise that will help to survive the current situation. But it did not seem to appear. Moreover, historians suggest that "there will be few national communities around the world torn by such sharp internal contradictions or as completely divided as the Armenian community" (Atamyan, 1955: 4). This was the result of an acute emotional trauma, and it seemed that the most tragic page of the history of the Armenians was coming, when they "would do what the most terrible oppression and persecution could not do with them, they would condemn themselves to cultural and national self-destruction" (Atamyan 1955, p. 5).

The only country that was not perceived as hostile in those years was Russia, moreover, Soviet Russia. It seemed to take some care of the Armenians. "The hatred for the Turks, born of the riot of 1915, and the indignation at the betrayal of Europe, which denied the Armenians after Lausanne, actually forces them to throw themselves into the arms of the savior Russia. It accepts the Armenians offended by ill treatment and rejected by the West. Using the terminology of psychoanalysts, Soviet Russia acquires the image of an all-powerful mother, where you can find help and protection from a hostile world" (Atamyan, 1955: 115). However, this leads to an even greater split in the Armenian diaspora: the main conflict flares up around the idea of communism, or rather, the admissibility or inadmissibility of assistance to Bolshevik Armenia. As a result, already in the 20s-30s we have Armenian culture split into three parts:

1) the population of Soviet Armenia fenced from its compatriots abroad by the Iron Curtain, not daring to ideologize under the fear of Kolyma, which has nothing but a plot of native land, hands and head in order to embody the idea;

2) Ramkavars-pragmatists who have a considerable share of the world capital and believe that even as a Soviet republic, Armenia is still more than nothing, that it is the germ of Armenian statehood and needs to be helped turning a blind eye to its Bolshevism, as well as the majority of the Armenian diaspora grouping around the Ramkavars, sympathetic to Soviet Armenia, completely unaware of what is happening in it, and free to invent any consoling tales for themselves; 
3) Dashnaktsutyun is the bearer of the heroic myth, who hates the Communists more than the Turks, and does not want any more deals. One of the modern leaders Dashnaktsutyun Anahit Ter-Minasyan wrote: "The most surprising thing is that the party managed to create a myth, in the good sense of the word, which allowed it to surround itself with believers rather than supporters" (Ter-Minasyan, 1991: 3).

These three elements formed the basis for the creation of a new Armenian structure. Moreover, if we consider that the action (genocide, indifference of the whole world) is equal to counteraction, then we can assume how powerful the internal energy potential of this structure became. This was needed to create a large national centre in the conditions of a totalitarian regime, universal internationalization, which would gather the Armenians from all over the world.

In such conditions, the process of self-organization of the Armenian ethnos began in the small territory that remained from its historic homeland, within the framework of the communist state, which the Armenians still did not perceive as hostile to themselves. Belief in the friendliness of Russia was important here, because it did not allow to despair to the end, to lose faith in everyone and become incapable of any positive actions. In the end, it gave hope (or the illusion of such) to ever be understood. The Armenians had financial support from the Ramkavars, among whom there were many large bankers (this support mainly relates to the 20s, then it became difficult to get it). They had a heroic myth of the Armenian statehood that had never been expressed or discussed, but firmly rooted in the consciousness. More precisely, maybe it was not even about statehood. It would be more correct to say that at some historical moments this myth had such an expression. For example, most of the Dashnaktsakans in the diaspora thought of it. In fact, it was the myth about heroic action in general. The form in which it could result was not predetermined in any way. There was no special emphasis on creating a special city. What became then the embodiment of this myth, Yerevan, was hardly ever perceived by anyone as a step towards statehood. Under the Russian patronage, the existence of Yerevan was viewed as something completely natural. Another thing is that it remained theirs and only theirs. But for a long time the Armenians almost did not realize it. They just built a city to live in it. And only when in the 1960s the popular movement for the creation of a monument to the victims of the genocide on the hill Tsitsernakaberd arose in Yerevan, the realization that all of Yerevan is a memorial city slowly began to appear.

There are not so many works about cities in Armenian literature, but there is one that dates back to the 1960 s and seems to be indirectly related to Yerevan. This is Perch 
Zeituntsyan's play “The Legend of the Destroyed City", which tells how the ancient king Arshak was building a legendary city. From the very beginning of the play, it is unclear what, in fact, the king is creating - the great city or the legend of the great city, a symbol. For the sake of this symbol, this legend, feats and crimes, murder and suicide are committed. But the city was wiped off the face of the earth. Already in prison, King Arshak says: "My idea of a free city will serve to revive this country. I created a legend for people, I created a memory. A memory that will pass from generation to generation" (Zeituntsyan, 1981: 130). Yerevan received its prototype in history.

Yerevan was not created consciously on the basis of a heroic myth. The Armenians themselves recognized this bright, multi-voiced city with a life that splashes the city as the embodiment of the myth, which, meanwhile, was happening not the way some groups within the Armenian ethnos could expect. And this myth, unrecognizable in its various interpretations, itself served as an additional source of confrontation and constituted the background of the functional intra-ethnic conflict. From this point of view, intra-ethnic conflict can be represented as playing up the main ethnic cultural theme, and this last, in turn, actually predetermines the actions of various intra-ethnic groups.

Thus, the pragmatic Ramkavar-Azatakan (from the very beginning, apparently, not trying to do anything more than improve the attitude of the Soviet authorities towards the Armenians) supported the idea of Armenian repatriation, which appeared in the Soviet special services at some point (for the purposes of the political situation of the post-war world). The fact that in the late 1940s Dashnaktsutyun, which was in acute confrontation with both the Soviet regime and Ramkavar-Azatakan, suddenly caught on to this idea, is much more interesting and unexpected. It did it somehow unexpectedly for itself. "In view of the relentless anti-Soviet position, which Dashnaktsutyun undoubtedly upheld, its policy on this issue seemed completely incredible. It encouraged Moscow's activities and also encouraged Armenians scattered throughout the world to return to their homeland ... It is not logic and realism, but sympathy for Armenians scattered around the world that eventually led to the 52nd Dashnak congress to vote for repatriation" (Atamyan, 1955: 138). There was little logic in this step, but "sympathy for the Armenians" is only a later interpretation of the events, because then, at the turn of the 40s-50s, no one could guarantee that foreign Armenians would really get to Yerevan, and not to Siberia via Yerevan. If the Armenians proceeded from the sense of realism, would there be many of those willing to come from Paris and Los Angeles, or from Lebanon flourishing at that moment, to test their fate in a Soviet socialist country? It was a massive spontaneous outburst, without any explicit ideological base. 
There was no such ideological base in Soviet Armenia. However, from the height of the past decades, it can be said that the then leaders of Armenia, who were striving for the leadership of the Union to turn a blind eye to the establishment of Yerevan, which did not fit into the total number of Soviet giant cities due to its mono-ethnicity, somehow paradoxically absorbed and synthesized in their actions both the pragmatic and the heroic alternatives, which forced them to risk their freedom and career in the name of this city, including the highest party one.

Therefore, in 1924, the Council of People's Commissars of Armenia discussed the plan for the reconstruction of Yerevan presented by the academician Alexander Tamanyan:

"The industry is located here," said the academician and pointed with the pointer.

Everyone looked at the desert station area. In those days, it was funny to talk about the industry of Yerevan: there was not even a single pipe ...

"You can see a city of 200 thousand inhabitants," said the academician, "you can see the capital." The administrative district is here.

It was an imaginary city centre. Imaginary area.

The eyes of Soviet People's Commissars were following the pointer.

"The district of culture, art and recreation," said the academician" (Avakyan, 1968: $54-55)$.

By the seventies, it was already a fully developed city with a million of inhabitants and at the same time a very dense social environment, a stable system of relations and seemingly unshakable traditions. The social and demographic processes taking place in Yerevan in those years clearly indicated that it was not an accidental settlement of disparate and diverse migrants, but an integral, unified and viable community.

The cultural-psychological environment of Yerevan created the possibility of forming a mono-ethical city. Migrants-foreigners did not succeed to settle down here. Aliens feel uncomfortable in the environment where there is a rapid intra-ethnic process. A new traditional society, like a young organism, rejects foreign bodies. It needs to stay alone with itself for some time, live and breathe within itself, crystallize, establish its structures and stereotypes.

For many centuries, the Armenians accustomed to living in foreign capitals, created their own.

Thus, the myth was embodied in a different way than could be expected by certain groups within the Armenian ethnic group, and this myth, unrecognizable in its various 
interpretations, itself served as an additional source of confrontation and constituted the background of the functional intra-ethnic conflict. The intra-ethnic conflict is fulfilled as playing up the main cultural theme, which predetermines the actions of various intra-ethnic groups.

Thus, the pragmatic Ramkavar-Azatakan from the very beginning, apparently, not trying to do anything more than improve the attitude of the Soviet authorities towards the Armenians, supported the idea of Armenian repatriation at some point for the purposes of the political situation of the post-war world. The fact that in the late 1940s Dashnaktsutyun, which was in acute confrontation with both the Soviet regime and Ramkavar-Azatakan, suddenly caught on to this idea, is much more interesting and unexpected. It did it somehow unexpectedly for itself.

At the turn of the 1940s and 1950s, no one could be sure that Armenians coming form abroad would actually get to Yerevan, and not to Siberia. If the Armenians proceeded from a sense of realism, would there be many of those willing to come from Paris and Los Angeles or from Lebanon flourishing at that moment, to test their fate in a Soviet socialist country? It was a massive spontaneous outburst, without any explicit ideological base.

There was no ideological base of repatriation in Soviet Armenia. However, from the distance of the past decades we can say the following. The leaders of Soviet Armenia in some paradoxical way absorbed and synthesized in their actions both pragmatic and heroic alternatives. In the name of this, risking personal freedom and the highest party career, they achieved the incredible: the leaders of the CPSU and the USSR seemed to close their eyes and not notice the formation of mono-ethnic Yerevan, a city that absolutely did not fit into the overall number of Soviet giants.

However, let us think, why did the dream of the Armenians come true? After all, Stalin was looking for conspiracies everywhere. There was no conspiracy here. Here, no one agreed with anyone about anything explicitly. Stalin searched everywhere for underground organizations. Here there were none. He was looking for a revolt. But the Armenians did not write and did not say anything disagreeable to the leader - they understood each other without words. This seems like a manifestation of the action of "civil disobedience", in many respects similar to the actions in 1903. Or even the action of disobedience not to the Soviet power itself, but disobedience to the whole world! The half exterminated, morally destroyed nation not only survived, but created a completely new form of their existence - their own Yerevan civilization. 


\section{References}

Avakyan, R. (1968). Molodost' drevnego goroda [The youth of the ancient city], Yerevan, Aiastan.

Akopyan, T.K. (1979). Ocherk istorii Erevana [The notes on the history of Yerevan], Yerevan, Mitk.

Antonyan, Y. (2011). Religiosity and religious identity in Armenia: Some current models and developments. In Acta Ethnographica Hungarica, 56 (2), 315-332.

Atamyan, S. (1955). Armianskaia obshchina. Istoricheskoe razvitie sotsial'nogo $i$ ideologicheskogo konflikta [Armenian community. Historical development of the social and ideological conflict], Moscow, Publishing house of political literature.

Berezovskii, V. (1908). Prichiny neuriadits na Kavkaze [The reasons of unstableness in the Caucasus]. Saint-Petersburg, Russkaia skoropechatnia.

Cavoukian, K. (2013). "Soviet mentality?" The role of shared political culture in relations between the Armenian state and Russia's Armenian diaspora. In Nationalities Papers, 41 (5), 709-729.

Dzhivelegov, A.K. (1906). Armiane v Rossii [The Armenians in Russia]. Moscow, Obschestvennaia pol'za publishing house.

Erkinyan, V. (1981). Armianskaia kul'tura v 1800-1917 godakh [Armenian culture in 1800-1917]. Yerevan, Publishing house of Armenian SSR.

Eisenstadt, Sh. (1973). Tradition, Change, and Modernity. New York, Sydney, Toronto.

Fehlings, S. (2015). "Intimacy and exposure - the Armenian "tun" and Yerevan's public space. In International Journal of Sociology and Social Policy, 35 (7/8), 513-532.

Fehlings, S. (2016). The ignoble savage in urban Yerevan. In Central Asian Survey, $35,(2), 195-217$.

Grigoryants, A.A. (1981). Armiane v Srednei Azii [The Armenians in Middle Asia]. Yerevan, Publishing house of Armenian SSR.

Hirs, S.J. (2013). Transnational Anti-Imperialism and the National Forces: Soviet Diplomacy and Turkey, 1920-23. In Comparative Studies of South Asia, Africa and the Middle, East 33 (2), 214-226.

Kasbarian, S., Oktem, K. (2014). Subversive friendships: Turkish and Armenian encounters in transnational space. In Patterns of Prejudice, 48 (2), 121-146.

Kanadpev, I.V. (1902). Ocherki Zacavkazskoi zhizni [Note on the Transcaucasian life]. Saint-Petersburg, A.E. Kolpinskii Publishing house. 
Karapetyan, R. (1986a). Formirovanie naseleniia Erevana [The formation of the population in Yerevan]. In Naselenie Erevana: etnosotsiologicheskoe issledovanie [Population of Yerevan: ethnocultural study]. Yerevan.

Karapetyan, E.T. (1986b). Etnicheskie osobennosti sem'i [Ethnic peculiarities of the family]. In Etno-sotsiologiia Erevana [Ethnic sociology of Yerevan]. Yerevan, Publishing house of Armenian SSR.

Karapetyan, E.T. (1986c). Predislovie [Introduction]. In Naselenie Erevana: etnosotsiologicheskoe issledovanie [Population of Yerevan: ethnocultural study]. Yerevan.

Khechumyan, V. (1983). K dobrym vremenam [About the good times]. In Literaturnaia Armeniia [Literature Armenia], 1.

Khudadov, V.N. (1926). Zakavkaz'e. Istoriko-ekonomicheskii ocherk [Transcaucasia. Historical and economic note]. Moscow-Leningrad, the Typography Centre of the Supreme Council of National Economy of the USSR.

Kocharyan, G.A. (1925). Nagornyi Karabakh [Mountainous Karabakh]. Baku, the Society of research of Azerbaijan.

Laycock, J. (2012). Armenian Homelands and Homecomings, 1945-9. The Repatriation of Diaspora Armenians to the Soviet Union. In Cultural and Social History, 9 (1), 103-123

Lehmann, M. (2015). Apricot Socialism: The National Past, the Soviet Project, and the Imagining of Community in Late Soviet Armenia. In Slavic Review, 74 (1), 9-31.

Mazinani, M. (2013). On Problems of Constructing "Genocidal Identity": The Armenians of Eastern Anatolia. In Journal of Muslim Minority Affairs, 33 (1), 29-40.

Mkrtchyan, N. (2015). Gramsci in Armenia: State-Church Relations in the PostSoviet Armenia. In Transformation, 32 (3), 143-154.

Priemskii, M. (1907). Armiane i sobytiia na Kavkaze [The Armenians and the event in the Caucasus]. Moscow, Publishing house of the society of useful books.

Ter-Ghazaryan, D.K. (2013). "Civilizing the city center": symbolic spaces and narratives of the nation in Yerevan's post-Soviet landscape. Nationalities Papers. In The Journal of Nationalism and Ethnicity, 41 (4): From Socialist to Post-Socialist Cities, 570-589.

Ter-Minasyan, A. (1991). Bezal'ternativnoi demokratii ne byvaet [There is no zero option democracy]. In Zerkalo mirovoi pressy [The mirror of the world mass media], Yerevan, 9.

Ter-Sarkisyants, A.E. (1972). Sovremennaia sem'ia u armian [Modern Armenian family], Moscow, Nauka. 
Shakhnazarian, N. (2013). Letters from the Soviet 'Paradise': The Image of Russia among the Western Armenian Diaspora? In Journal of Eurasian Studies, 4 (1), January, $8-17$.

Vadin, V. (1907). Kavkazskie nabroski [Caucasian sketches]. Saint-Petersburg, Pushkinskaia skoropechatnia.

Vsepoddaneishii otchet za 8 let upravleniia Kavkazom General-Ad'iutanta gr. Vorontsova-Dashkova [The Most Loyal Report on the 8 years of managing the Caucasus of the Adjutant General Vorontsov-Dashkov] (1913). Saint-Petersburg, State Publishing House.

Zeituntsyan, P. (1981). P'esy [Plays]. Yerevan, Sovetakan grokh.

\title{
Как меняется картина мира? \\ (На примере формирования Еревана \\ как социально-психологической общности)
}

\section{С.В. Лурье}

Социологический институт РАН Россия, 194214, Санкт-Петербург, пр. Костромской, 31

\begin{abstract}
Статья посвящена вопросу самоорганизащии общества. Такая самоорганизащия может происходить спонтанно и быть проявлением этнокультурных процессов не по решению общественных и политических деятелей, хотя направленность общественных трансформаций зависит от их иенностных доминант. В основе спонтанных общественных трансформаций лежит функииональный внутрикультурный конфликт. Механизм трансформации общества рассматривается на примере формирования в середине ХХ века Еревана как социокультурной общности.

Ключевые слова: этнокультура, этнокультурные процессы, самоорганизащия общества, культурная тема, функииональный конфликт.
\end{abstract}

Научная специальность: 24.00.00 - культурология. 